\title{
SYNTACTIC ANALYSIS OF SENTENCE PATTERNS AND TYPES OF BBC NEWS ARTICLES
}

\author{
Erina Andriani, Barli Bram
}

andrianierina@gmail.com, correspondence: barli@usd.ac.id

English Education Master's Program, Sanata Dharma University

Sleman, Yogyakarta, Indonesia

\begin{abstract}
Sentence patterns and types play a crucial role in helping writers make their articles attractive. However, few studies analyzed the sentence patterns and types used in news articles. Therefore, this study aimed to explore the sentence patterns and types used in shaping news articles. The researchers used a syntactic analysis to examine the sentences. The data were collected from ten BBC news articles published in October 2020. The purposive sampling was used, and the data gathering instrument was structured observation sheets. The gathered data were calculated using percentages. The results showed five sentence patterns used, namely $\mathrm{S}+\mathrm{V}, \mathrm{S}+\mathrm{LV}+\mathrm{SC}, \mathrm{S}+\mathrm{V}+\mathrm{O}$, $\mathrm{S}+\mathrm{V}+\mathrm{DO}+\mathrm{OC}$, and $\mathrm{S}+\mathrm{V}+\mathrm{IO}+\mathrm{DO}$. It was also found that four sentence types, namely simple, compound, complex, and compound-complex sentences, were used. Among the used sentence patterns, $\mathrm{S}+\mathrm{V}+\mathrm{O}$ was the most frequent (42\%), and the most frequent sentence type was the complex sentence $(52.6 \%)$.
\end{abstract}

Keywords: BBC news article, sentence pattern, sentence type, syntactic analysis

\section{INTRODUCTION}

A news article is one of the forms of media. Mass media is one of the most excellent discourse materials (Goatly, 2000, p. 247). It can be broadcasted through audio or video, though it can also be printed or digital articles. People can get access to news articles by looking them up on the internet for online reading. Because the digital form grants more accessibility for the readers, news broadcasting companies have added online news articles as their feature nowadays. As one of the means of the report by the media, its exciting feature, as seen from syntactic and stylistic perspectives, lies in the power that it has which is gained from the used ways to report a particular event or person (Thomas \& Wareing, 1999, p. 52).

To make a news article, the author needs writing skills to convey the report to be engaging by varying language uses to keep reading. The author can use various sentence patterns and types to vary the language uses, so the articles will not be monotonous (Wiredu, 2012; Ernawati, 2014). There are several patterns one can choose to construct a sentence (Quirk \& Greenbaum, 1973). Each pattern accommodates the writer to compose a sentence based on the information piece that they have. Aside from the sentence patterns, there are also sentence types (Bornstein, 1977, p. 245). Both the patterns and types are the tools to frame the writing as the authors wish the readers to see, so they have similar ideas in mind. Many studies include news articles as their objects of observation (Indarti, 2020; Msuya, 2020; Olugbenga, 2020; Ziyayeva, 2020). However, to the best of our knowledge, the study on sentence patterns and types in newspaper articles is not extensively explored yet.

Research Questions:

1. What sentence patterns were used in the BBC News articles published in October 2020?

2 . What sentence types were used in the BBC News articles published in October 2020?

In the news articles, the sentences are made to give a different level of length and depth. Those sentences are made to express the ideas, minds, or messages from the writers (Bornstein, 1997; Hogue, 1995) that follow certain grammar (Hurford, 1983; McGregor, 
2007). In those sentences, they follow a certain structure so the readers can understand them. To construct an understandable sentence in the English language, the words are not randomly put together (Aitchison, 2003). A sentence is made of a subject and a predicate (Nordquist, 2016; Bornstein, 1977; Hogue, 1995; Alexander 1990). Those can be added with other words to construct meaning. In English language, there are some sentence patterns to compose a sentence: Subject + Verb (intransitive), Subject + Linking Verb + Subject Complement, Subject + Verb + Object, Subject + Verb + Direct Object + Object Complement, and Subject + Verb + Indirect Object + Direct Object (Brown, 2000; Quirk \& Greenbaum, 1973; Burton-Roberts, 2016; Morley, 2000; Valin and Lapolla, 1997; Koopman, Sportiche, \& Stabler, 2013). The adverbial phrase can be added before or after a verb, so it is a special feature (Quirk \& Greenbaum, 1973).

Those patterns are English sentence patterns. They consist of smaller units that define each component, namely phrases (O'Grady, 2010). Phrases are groups of words. Each phrase has a head, its corresponding part of speech, and modifier(s) (Poole, 2002). According to House and Harman (1950), there are four phrases based on their functions: noun, verb, adjective, and adverbial phrases ( $\mathrm{p}$. 12). For example, the subject is mainly constructed from a noun phrase, which has a noun as the head (Matthews, 1997). however, the subject can also be in the form of pronouns. The other phrases also have different heads depending on their categories.

After knowing the structure, it is essential to know that they are used to make a sentence. However, writers do not write only simple sentences. The sentence itself is an independent clause that can stand alone (Radford, 1997). When there is only one independent clause in a sentence, it is a simple sentence (Murcia \& Freeman, 1999; Morley, 2000). If there are two independent clauses in a sentence, it is a compound sentence (Morley, 2000; Reyner, 2016; Putrayasa, 2011; Murcia \& Freeman, 1999). Aside from those, there are other types of sentences, namely complex and compound-complex sentences (Bornstein, 1977; Morley, 2000). The complex sentence has independent and one or more dependent clauses, while the compound-complex sentence has a dependent and one or more independent clauses. The use of these types differs in contexts and the writers. From the study conducted by Ernawati (2013) on EFL students' writing, the students used simple sentences the most. That result is in line with the result of Qamariah's (2015) study. On the contrary, from the study by Jegede (2020) on Trump's speech, it was found that complex sentence was used the most.

This study aims to analyze the sentence patterns and types of sentences by employing a syntactic analysis since a sentence is the highest unit of syntactic analysis (O'Grady, 2010; Roberts, 1964; Bornstein, 1997). Some studies used syntactic analysis to study sentences and their elements (Agajie, 2020a; Agajie, 2020b; Yasmin, Indrawati, and Rahayuni, 2017; Leláková and Belúchová, 2020). Furthermore, syntax explores the rules of sentence formation (O'Grady, 2010; Radford, 1997; Miller, 2002; Finch, 2005; Andrew, 2006); hence syntactic analysis would be a helping tool for this study. After reviewing the literature, this research used the theories from Quirk \& Greenbaum (1973) and Brown (2000) to find the sentence patterns and theories from Murcia and Freeman (1999), Reyner (2016), and Bornstein (1977) for the sentence types.

\section{METHOD}

This paper wanted to explore the sentence patterns and types from the BBC news articles. The data were gathered from ten articles in five different categories (i.e., future, news, sport, work-life, and culture) from https://www.bbc.com. Two articles were taken from each category. The analyzed articles were published in October 2020. To gather the articles, the researchers used purposive sampling, which could help gather the data aligned with the criteria set by the researchers (Ary, Jacobs, Sorensen, \& Razavieh, 2010). To help analyze the document, syntactic analysis was used to investigate the structure and elements that construct sentences (Bergmann, Hall, and Ross, 2007, p. 671).

The reviewed theories about sentence patterns and types were used to construct an instrument. To gather the data, this study employed observation, which gathered the data as they naturally were without any manipulation (Streefkerk, 2020). The researchers created structured observation sheets for each research question. They were 
used to record the data from the document that the researchers observed (Lambert, 2012). For the first instrument about sentence pattern, the theories from Quirk \& Greenbaum (1973) and Brown (2000) were used, which resulted in five categories: 1) Subject+Verb (intransitive), 2) Subject+Linking Verb+Subject Complement, 3) Subject+Verb+Object, 4) Subject+Verb+Direct Obj.+Obj. Complement, and 5) Subject+Verb+Indirect Obj.+Direct Obj. For the second one, the theories from Murcia and Freeman (1999), Morley (2000), Reyner (2016), and Bornstein (1977) were used, which resulted in four categories: simple, compound, complex, and compound-complex types. The researchers used percentages to show the frequency to analyze the data, and they were discussed descriptively.

\section{RESULTS AND DISCUSSION}

In this section, the results for each research question are presented. The first part discusses the results regarding the sentence patterns found in the BBC News articles. Then, the following part is the results regarding the sentence types.

\section{What sentence patterns were used in the $B B C$ News articles published in October 2020?}

This study divided sentence patterns into five categories: pattern $1(S+V)$, pattern 2 $(S+L V+S C)$, pattern $3(S+V+O)$, pattern 4 $(S+V+D O+O C)$, and pattern $5(S+V+I O+D O)$. This study observed ten articles on five different themes. The selected news articles revealed that all of the patterns existed in the reviewed articles.

Table 1. Sentence Patterns on BBC News Articles

\begin{tabular}{|c|c|c|c|c|c|c|}
\hline No. & Title & $\mathbf{1}$ & 2 & 3 & 4 & 5 \\
\hline \multicolumn{7}{|c|}{ Culture } \\
\hline 1 & $\begin{array}{l}\text { Velázquez's Las Meninas: A detail that decodes a masterpiece By } \\
\text { Kelly Grovier }\end{array}$ & 40 & 49 & 63 & 3 & - \\
\hline 2 & A Change Is Gonna Come: One of soul's greatest songs By Greg Tate & 26 & 25 & 37 & 3 & - \\
\hline \multicolumn{7}{|c|}{ Future } \\
\hline 3 & $\begin{array}{l}\text { How a silence solved the weird maths inside black holes By Patchen } \\
\text { Barss }\end{array}$ & 61 & 47 & 77 & 1 & 1 \\
\hline 4 & Is wind power's future in deep water? By Paul Hockenos & 49 & 33 & 43 & 2 & - \\
\hline \multicolumn{7}{|c|}{ News } \\
\hline 5 & France teacher attack: Rallies held to support beheaded Samuel Paty & 21 & 13 & 40 & - & - \\
\hline 6 & Belly Mujinga's death: Searching for the truth By Rianna Croxford & 139 & 70 & 159 & 2 & 8 \\
\hline \multicolumn{7}{|c|}{ Sport } \\
\hline 7 & $\begin{array}{l}\text { Tottenham 3-3 West Ham: Manuel Lanzini Stunner Seals Dramatic } \\
\text { Draw By Tim Oscroft }\end{array}$ & 31 & 24 & 64 & 3 & - \\
\hline 8 & $\begin{array}{l}\text { Len Johnson: The boxer with } 93 \text { wins who could never become British } \\
\text { champion By Christian Brooks, Nathanael Hutchinson \& Sanjeev } \\
\text { Shetty }\end{array}$ & 67 & 51 & 54 & 2 & 1 \\
\hline \multicolumn{7}{|c|}{ Worklife } \\
\hline 9 & Are Europe's night trains back in fashion? By Maddy Savage & 46 & 51 & 105 & - & - \\
\hline \multirow[t]{3}{*}{10} & Why the world's passports look different By Hephzibah Anderson & 52 & 34 & 53 & 4 & 1 \\
\hline & Total & 532 & 397 & 695 & 20 & 11 \\
\hline & Percentage & 32.1 & 24 & 42 & 1.2 & 0.7 \\
\hline
\end{tabular}

Note: $1: S+V, 2: S+L V+S C, 3: S+V+O, 4: S+V+D O+O C$, and $5: S+V+I O+D O$

The results of sentence patterns across the article categories are presented in table 1. The most used sentence pattern from all categories was pattern $3(S+V+O), 42 \%$ of the total used sentence patterns. The second most used pattern, $32.1 \%$ used in all articles, was pattern $1(S+V)$. Pattern $2(S+L V+S C)$ was the third most used pattern (24\%). The second least used one was pattern $4(S+V+D O+O C)$, which was $1.2 \%$ of the total sentences, while the least used one $(0.7 \%)$ was pattern 5 $(S+V+I O+D O)$.

The sentence pattern that was primarily used in the ten observed articles was the $\mathrm{S}+\mathrm{V}+\mathrm{O}$ pattern. Below are the sentence example taken from the articles:

[1] It also triggered hallucinations.

[2] The opening lyrics paint a scene of impoverished birth in the country's Delta outback. 
[3] In the late 1950s, observations from the emerging field of radio astronomy threw these ideas into turmoil.

To be categorized into a sentence with an $S+V+O$ pattern, the subject, predicate, and object elements should be in the said sentence. In example [1], the subject is a pronoun: "it." In example [2] and [3], the subjects are noun phrases; "The opening lyrics" in example [2] and "observations from the emerging field of radio astronomy" in example [3]. The subjects then are followed by transitive verbs, which are action verbs that have objects. In example [1], the verb phrase is "also triggered", in example [2] it is "paint", and in example [3] it is "threw". The object in example [1] is "hallucinations," in example [2], it is "a scene of impoverished birth in the country's Delta outback," and example [3] has "these ideas" as the object. Example [3] also has adverbial phrases "in the late 1950s" and "into turmoil." Those adverbial phrases in that example and many other sentences can be placed either at the beginning or end of the sentence, which is following the Quirk \& Greenbaum's (1973) theory. Those examples, and most sentences $(42 \%)$, fit in the $S+V+O$ pattern because those elements existed in them. This pattern appeared the most in every observed article, except in articles 4 and 8.

The second most used sentence pattern was the $S+V$ pattern. Below are the examples from the observed articles:

[4] At Scotland's easternmost headland, the old fishing port of Peterhead juts out into the North Sea.

[5] Four close relatives of the suspect were detained shortly after the killing.

[6] On the morning of 21 March, Belly and her colleague Motolani Sunmola were working on the concourse.

The $S+V$ pattern only requires a subject and a verb. The subjects in those examples are "the old fishing port of Peterhead" (example [4]), "four close relatives of the suspect" (example [5]), and "Belly and her colleague Motolani Sunmola" (example [6]). In example [6], a compound subject is two subjects of equivalent position as the subject of a sentence. In this case, the compound subject is "Belly and her colleague Motolani Sunmola," in which two parties (Belly and Motolani Sunmola) become the subject of the sentence. The verb phrases in example [4], "juts out," and in example [6], "were working on," are phrasal verbs, while in example [5], "were detained," it is a passive voice. These examples and the other $32.1 \%$ of sentences that used this pattern do not have any object in any form. Nevertheless, it is the second most used pattern in every observed article except in articles 1, 4, 8, and 9.

The third most used pattern was the $S+L V+S C$ pattern. Linking verbs describe the subject, not showing the action taken by the subject. Linking verbs may be in the form of to be and some particular action verbs. Below are the sentence examples:

[7] Is it a lesson for the players?

[8] The lack of acceptance for black boxers wasn't only a British issue either.

[9] It's definitely a European trend. $S+L V+S C$ pattern differs from pattern 3 $(S+V+O)$ in its verb. While in pattern 3 , the verb is transitive, a verb that has an object and shows the action taken by the subject to the object, in this pattern, the verb does not have an object, and it describes the subject, which is why it is different from the intransitive verb. In the examples, the subjects are "it" (examples [7] and [9]) and "the lack of acceptance for black boxers" (example [8]). The linking verb "is" (examples [7] and [9]) and "wasn't" (example [8]) describe those subjects. Therefore, those examples have to be as the linking verb. The description is the subject complement, which can be in the form of a noun or adjective. In all three examples, however, they are in the form of noun phrases ("a lesson" in example [7], "only a British issue either" in example [8], and "definitely a European trend" in example [9]). $24 \%$ of the sentences in the observed articles, including examples [7], [8], and [9], used the $S+L V+S C$ pattern. This pattern was the third most used pattern in every article except in articles 1 and 9.

The pattern with a low percentage of usage was the $S+V+D O+O C$ pattern. In this pattern, the object has a description called object complement, similar to the subject complement. Below are the examples:

[10] On the other hand, the rebounding glare of the mirror bounces our attention back out of the painting to ponder the plausible position of royal spectres whose vague visages haunt the work. 
[11]...which Cooke said made him embarrassed for not having written his own forthright take on racism and racial protest.

[12] Nevertheless, the after-life of the composition in the African-American protest hymnal canon finds it still essential and indelible.

This pattern, aside from having subject, verb, and object, requires an object complement, which gives further description to the object. The subjects are "the rebounding glare of the mirror" in example [10], "which Cooke said" in example [11], and "the after-life of the composition in the African-American protest hymnal canon" in example [12]. The verbs are transitive; they are "bounces" in example [10], "made" in example [11], and "finds" in example [12]. The objects can be in a noun phrase, like "our attention" in example [10], or pronoun, like "him" in example [11], and "it" in example [12]. However, the object complement can be a noun or adjective phrases, though, in those examples, they are all adjectives. In example [10], the object complement is "back", "embarrassed" in example [11], and "still essential and indelible" in example [12]. Sentences comprised $1.2 \%$ of the total sum of the observed sentences, and this pattern became the fourth most used pattern in each observed article except in article 6.

The least used pattern was the $S+V+I O+D O$ pattern. Instead of object complement, two objects are corresponding to the verb. Below are the examples:

[13]...requesting that rulers of lands beyond the Euphrates grant him safe passage to Judah.

[14]A GTR spokesperson told the BBC that...

[15] Most boxers will tell you the punches don't hurt...

The $S+V+I O+D O$ pattern was the least used pattern in the observed articles. Only four of the ten articles had this pattern (articles 3, 6, 8 , and 10). As the pattern suggests, it has a subject, a verb, and two objects in a sentence. The subject in example [13] is "rulers of lands beyond the Euphrates," in example [14], it is "a GTR spokesperson," and it is "most boxers" in example [15]. The used verb is transitive; it is "grant" in example [13], "told" in example [14], and "will tell" in example [15]. According to
Morley (2000), "The indirect objects are usually the recipients or beneficiaries of the action." The indirect object can be pronouns like "him" in example [13] and "you" in example [15], or a noun like "the $B B C$ " in example [14]. The indirect objects are the recipients of the direct objects, which are "safe passage to Judah" in example [13], "that" in example [14], and 'the punches don't hurt" in example [15]. Some nouns can have clauses as modifiers which make them longer. This pattern was only found in $0.7 \%$ of the observed sentences, thus made it the least used sentence pattern.

As mentioned in the previous paragraph, some sentences had more than one clause in them. Below are the examples from the articles:

[16] Whenever the two met up, they never lacked for conversation, and their talk on this occasion was non-stop and wide-ranging.

[17] Fixed-bottom offshore wind will be expanded far beyond what it is today, but it will run out of space, too, like onshore has in some places.

[18] He followed Mr. Paty as he walked home from work.

A sentence is a clause that can stand alone (Radford, 1997). However, some clauses cannot stand alone, as they are dependent on other clauses, become modifiers, or just are other independent clauses connected with conjunctions to construct a more complex sentence. In this case, they are treated as different clauses that may have different patterns in a sentence. For example, in example [16], there are three clauses: "the two met up," "they never lacked for conversation," and "their talk on this occasion was non-stop and wideranging." The first and second clauses have an $S+V$ pattern, while the third one has an $S+L V+S C$ pattern. Example [17] has four clauses: "fixed-bottom offshore wind will be expanded," "it is today," and "it will run out of space," and "onshore has in some places." The first, third, and fourth clauses have an $S+V$ pattern, while the second clause has an $S+L V+S C$ pattern. Example [18] only has two clauses: "he followed Mr. Paty" and "he walked home from work." The first clause is in the $S+V+O$ pattern and the second one in the $S+V$ pattern.

Conjunctions can be used to connect two clauses to become a sentence. However, 
conjunctions, like and, but, or, can also connect subjects or predicates into a compound subject or compound predicate, which is still counted as one clause or sentence. Example [6] is the example of a compound subject, and the researcher found several cases of compound predicates presented below:

[19] ...his shot curled just wide and left West Ham with a slight chance...

[20] He was active in the community in Moss Side, Manchester, and frequently intervened in cases involving racial discrimination.

[21] Written on vellum in a clear, ornate hand, it included England's King Charles I signature, and, being far from pocket-sized, has been folded many times.

In some cases, the compound predicates have a similar type of verbs, and in some cases, they do not. In example [19], the predicate of the sentence comprises of two verb phrases: "curled just wide," which has an intransitive verb, and "left West Ham with a slight chance," which has a transitive verb. In example [20], there are two verb phrases as well: "was active in the community in Moss Side, Manchester," which has a linking verb, and "frequently intervened in cases involving racial discrimination," which has an intransitive verb. Similarly, example [21] has two verb phrases: "included England's King Charles I signature," which has a transitive verb, and "has been folded many times," which has an intransitive verb. The types of verbs and objects usually affect the pattern of a sentence. Therefore, the researchers considered sentences with these compound predicates as a particular case and did not count them into the calculation.
On the contrary, several sentences in the articles did not meet the minimum requirement of being a sentence. They are either only subjects or only predicates. Below are the examples:

[22] The crest on the cover?

[23] Contradicted.

These 'sentences' were not included in the calculation. For example, [22] does not have any predicate, while in example [23], it does not have any subject. While some sentences might only have a predicate (such as: "Go!" or "Come here!"), example [23] is not an imperative sentence and is ambiguous, whether it acts as a past form of a verb (V2), a past participle form for passive voice (V3), or an adjective. The researchers did not consider those as sentences and did not include them in the percentage for either research question.

\section{What sentence types were used in the BBC News articles published in October 2020?}

The second research question of this study is about sentence types. This study divided them into four categories: simple (1), compound (2), complex (3), and compoundcomplex (4). After observing the ten articles, it was found that those sentence types were used.

There are four sentence types used to categorize the sentences in BBC News articles. The results of the sentence types from all five observed categories are presented in table 2 . The most used sentence type in those articles was the complex sentence, which was more than half of the total observed sentence (52.6\%). The second most used type was a simple sentence $(33.5 \%)$. Finally, the types of low use were compound-complex sentences (8.8\%) and compound sentences (5.1\%).

Table 2. Sentence Types on BBC News Articles

\begin{tabular}{|c|c|c|c|c|c|}
\hline No. & Title & 1 & 2 & 3 & 4 \\
\hline \multicolumn{6}{|c|}{ Culture } \\
\hline 1 & $\begin{array}{l}\text { Velázquez's Las Meninas: A detail that decodes a masterpiece By Kelly } \\
\text { Grovier }\end{array}$ & 15 & - & 37 & 6 \\
\hline 2 & A Change Is Gonna Come: One of soul's greatest songs By Greg Tate & 21 & 3 & 26 & 2 \\
\hline \multicolumn{6}{|c|}{ Future } \\
\hline 3 & How a silence solved the weird maths inside black holes By Patchen Barss & 39 & 6 & 45 & 7 \\
\hline 4 & Is wind power's future in deep water? By Paul Hockenos & 17 & 1 & 35 & 7 \\
\hline \multicolumn{6}{|c|}{ News } \\
\hline 5 & France teacher attack: Rallies held to support beheaded Samuel Paty & 21 & 1 & 16 & 2 \\
\hline 6 & Belly Mujinga's death: Searching for the truth By Rianna Croxford & 47 & 5 & 95 & 18 \\
\hline \multicolumn{6}{|c|}{ 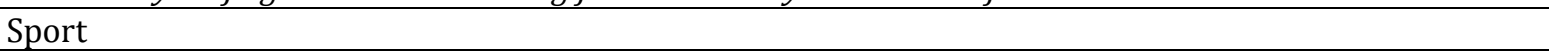 } \\
\hline 7 & $\begin{array}{l}\text { Tottenham 3-3 West Ham: Manuel Lanzini Stunner Seals Dramatic Draw } \\
\text { By Tim Oscroft }\end{array}$ & 16 & 7 & 24 & 8 \\
\hline
\end{tabular}




\begin{tabular}{lrrrrc}
\hline 8 & $\begin{array}{l}\text { Len Johnson: The boxer with 93 wins who could never become British } \\
\text { champion By Christian Brooks, Nathanael Hutchinson \& Sanjeev Shetty }\end{array}$ & 31 & 9 & 41 & 8 \\
\hline \multicolumn{2}{l}{ Worklife } & & & \\
\hline 9 & Are Europe's night trains back in fashion? By Maddy Savage & 24 & 3 & 52 & 4 \\
\hline 10 & Why the world's passports look different By Hephzibah Anderson & 28 & 4 & 35 & 6 \\
\hline \multicolumn{7}{r}{ Total } & $\mathbf{2 5 9}$ & $\mathbf{3 9}$ & $\mathbf{4 0 6}$ & $\mathbf{6 8}$ \\
\hline
\end{tabular}

Note: 1: simple sentence, 2: compound sentence, 3: complex sentence, 4: compound-complex sentence

The sentence type that was used the most was a complex sentence. It has an independent clause and one or more dependent clauses. Below are the sentence example taken from the articles:

[24] A small clay pot in Diego Velázquez's Las Meninas could hold the key to unlocking the mysterious 17thCentury painting, argues Kelly Grovier.

[25] They also obliquely command we note how long those pleas have gone unheard.

The complex sentence was used in more than half of the total sum of the sentences (52.6\%). A dependent clause can be identified by seeing whether it has subordinating conjunction or standing alone as a complete, independent sentence. In example [22], there are two clauses: "A small clay pot in Diego Velázquez's Las Meninas could hold the key..." as the independent clause and "argues Kelly Grovier" as the dependent clause. In example [23], there are three clauses: "they also obliquely command" as the independent clause and "we note how long" and "those pleas have gone unheard" as the dependent clauses. This type of sentence also dominated the observed articles except in article 5.

The second most used sentence type was a simple sentence. This type of sentence only has one clause per sentence. Below are the examples:

[26] The debate came to a head at the International Congress on General Relativity and Gravity in London later that year.

[27] Is the answer to go farther out to sea?

A simple sentence consists of a single independent clause that can stand alone. Example [24] shows that a single clause can be quite long. It only has a subject (the debate) and a predicate (came), with five adverbial phrases. On the other hand, example [25] shows a simple sentence in an interrogative form. Its subject is "the answer," the predicate is a linking verb "is," and the subject complement is "to go farther out to sea." Both examples and 257 other sentences $(33.5 \%$ of the total sentences) used this sentence type and became the second most used sentence type in every observed article except in article 5.

The third most used sentence type was compound-complex. This sentence type has one dependent clause and two or more independent clauses. It was used in 68 out of 772 sentences (8.8\%). Below are the examples:

[28] West Ham improved markedly in the second half, but when Kane hit the post with 12 minutes to go there was no sign that the final result would be anything other than another win for Spurs.

[29] Her symptoms started to escalate and on 2 April, when she was struggling to breathe, Lusamba called an ambulance.

The compound-complex sentence has at least three clauses in one sentence, one of which is a dependent clause. The independent clauses are identified by observing whether there is any coordinating conjunction or semicolon (;) or not. In example [26], there are four clauses: "West Ham improved markedly in the second half" and "there was no sign" as the independent clauses and "when Kane hit the post with 12 minutes to go" and "that the final result would be anything other than another win for Spurs" as the dependent clauses. Example [27] has three clauses: "her symptoms started to escalate" and "Lusamba called an ambulance" as the independent clauses, and "when she was struggling to breathe" as the dependent clause. This sentence type was the third most used type in all observed articles except in articles 3 and 8.

The least used sentence type is a compound sentence. This sentence type has two or more independent clauses connected by 
a coordinating conjunction or a semicolon. Below are the examples:

[30] Johnson, then in his early 50s, was teetotal but he was ordering around for his friends.

[31] Sleeper trains were making a slow comeback in Europe before the pandemic, but will Covid-19 help or hinder a renaissance of long-distance rail travel?

The compound sentence type was used in $5.1 \%$ of the total observed sentences. This type of sentence has at least two independent clauses. In the example [28], the clauses "Johnson, then in his early 50s, was teetotal" and "he was ordering around for his friends," are independent clauses connected with coordinating conjunction 'and.' Meanwhile, example [29] has two clauses "sleeper trains were making a slow comeback in Europe before the pandemic" and "will Covid-19 help or hinder a renaissance of long-distance rail travel" (categorized as independent clauses with positive and interrogative forms). They are connected with the conjunction 'but.' Such a sentence was the least used, except in articles 3 and 8.

News articles provide much information in compact delivery and increase complexity. It causes less engaged readers as it is "heavyladen and unwieldy" (Wiredu, 2012). To bridge the engagement with the expansion and compression (Wiredu, 2012), writers can vary the sentence types and or various patterns. Complex sentences can be cut into simple ones with elaborate patterns $(\mathrm{S}+\mathrm{V}+\mathrm{DO}+\mathrm{OC}$ or $\mathrm{S}+\mathrm{V}+\mathrm{IO}+\mathrm{DO}$ ) to assist expansion, while complex sentences can adopt simpler patterns
$(\mathrm{S}+\mathrm{V}, \quad \mathrm{S}+\mathrm{LV}+\mathrm{SC}, \quad \mathrm{S}+\mathrm{V}+\mathrm{O})$ to provide compression. Hence, readers are not burdened with overwhelming information and complex sentence organization. The results of this study support those strategies, as the high use of complex sentences, which is in line with Wiredu (2012), Ernawati (2014), and Jegede (2020), also adopt high use of the $\mathrm{S}+\mathrm{V}+\mathrm{O}$ pattern.

\section{CONCLUSION}

This paper explored sentence patterns and types in ten BBC News articles from five different categories. The results showed that various sentence patterns were used in the BBC News articles. All five patterns $(S+V$, $S+L V+S C, S+V+O, S+V+D O+O C$, and $S+V+I O+D O)$ were used with a different number of appearances. The most used pattern is $S+V+O$, followed by $S+V, S+L V+S C, S+V+D O+O C$, and $S+V+I O+D O$ as the least used pattern. There are two special cases where the researchers did not include the sentence in the calculation. The first case was about compound predicate with two different types of verbs or objects, and the second one was the sentences without at least one subject and one predicate.

The researchers found that all sentence types were used in BBC News articles. However, the use of those sentence types varied in number. The most frequently used type was a complex sentence, followed by simple, compound-complex, and compound sentences as the least used one. The lines without at least one subject and one predicate were not regarded as sentences, so they were excluded in the calculation.

\section{REFERENCES}

Agajie, B. A. (2020a). Syntactic structure of adjective, adverb, and prepositional phrases of Awgni. LLT Journal, 23(2), 368-382. doi:10.24071/llt.v23i2.2527.g2011.

Agajie, B. A. (2020b). THE SYNTACTIC STRUCTURE OF AWGNI NOUN PHRASES. LiNGUA: Jurnal Ilmu Bahasa dan Sastra, 15(2), 111 - 122. doi:https://doi.org/10.18860/ling.v15i2.9079

Aitchison, J. (2008). Linguistics: Teach yourself. London: Hodder Headline.

Alexander, L. (1990). Longman English grammar practice for intermediate students. London: Longman Group UK Limited.

Andrew, C. (2006). Syntax: A generative introduction (2nd ed.). Oxford: Wiley-Blackwell.

Ary, D., Jacobs, L. C., Sorensen, C., \& Razavieh, A. (2010). Introduction to research in education (8th ed.). Belmont: Wadsworth. 
Bergmann, A., Hall, K. C., \& Ross, S. M. (2007). Language files: Materials for an introduction to language and linguistics (10th ed.). Columbus: The Ohio State University Press.

Brown, D. H. (2000). Principles of language learning and teaching (4th ed.). New York: Longman.

Burton-Roberts, N. (2016). Analyzing sentence: An introduction to English syntax (4th ed.). New York: Routledge.

Ernawati, A. (2014). An analysis types of sentences used by the students' essay writing at the third semester of IAIN Tulungagung in the 2013/2014 academic years. Tulungagung: IAIN Tulungagung.

Finch, G. (2005). Key concepts in language and linguistics. New York: Palgrave Macmillan.

Goatly, A. (2000). Critical reading and writing. London: Routledge.

Bornstein, D. D. (1977). An introduction to transformational grammar. New York: Winthrop Publisher.

Hogue, A. (1995). Academic writing. New York: Longman.

House, H. \& Harman, S. (1950). Descriptive English grammar (2nd ed.). New Jersey: Prentice-Hall.

Hurford, J. R. (1983). Semantics: A coursebook. London: Cambridge University Press.

Indarti, D. (2020). Lexical richness of newspaper editorials published in Southeast Asian countries. Studies in English Language and Education, 7(1), 55-69. doi: 10.24815/siele.v7i1.15032.

Jegede, O. O. (2020). Syntactic analysis of Donald Trump's inaugural speech. Studies in Literature and Language, 21(1), 93-98. doi:10.3968/11827.

Koopman, H., Sportiche, D., \& Stabler, E. (2013). An introduction to syntactic analysis and theory. New Jersey: Willey-Blackwell.

Lambert, M. (2012). A beginner's guide to doing your education research project. London: Sage.

Leláková, E. \& Belúchová, A. (2020). Syntactic analysis of sentence adverbials observed in the victorian novel Jane Eyre. Arab World English Journal, 11(2), 49-58. doi:10.24093/awej/vol11no2.4.

Matthews, P. H. (1981). Syntax. Cambridge: Cambridge University Press.

McGregor, W. B. (2009). Linguistics: An introduction. London: Continuum International Publishing Group.

Miller, J. (2002). Introduction to English syntax. Edinburgh: Edinburgh University Press Ltd.

Morley. (2000). Syntax in functional grammar. London: Continuum.

Msuya, E. A. (2020). Analysis of newspaper headlines: A case of two Tanzanian English dailies. Journal of Education, Humanities, and Sciences, 8(2).

Murcia, M. C. \& Freeman, D. L. (1999). The grammar book: An ESL/EFL teacher's course (2nd ed.). Boston: Heinle ELT.

Nordquist, R. (2016). Grammar basics: Sentence parts and sentence structure. Retrieved from http://grammar.about.com/od/rs/fl/sentence-structure.html.

O'Grady, W., (2010). An Emergentist Approach to Syntax, in Narrog, H. \& Heine, B (eds.). The Oxford handbook of linguistic analysis, 257-283. New York: Oxford University Press.

Olugbenga, A. S. (2020). A linguistic-stylistic analysis of newspaper headlines of Metele attack on Nigerian army by Boko Haram insurgents. International Journal of Scientific and Research Publications, 10(2), 880-887. doi: 10.29322/IJSRP.10.02.2020.p98108. 
Putrayasa, I. B. (2011). Studi penelusuran miskonsepsi dalam pembelajaran sintaksis (tata kalimat) dengan model konstruktivisme berpendekatan inkuiri pada siswa kelas I SMPN di kota Singaraja, kabupaten Buleleng, provinsi Bali. Prosiding Konferensi Internasional Masyarakat Linguistik Indonesia.

Poole, G. (2002). Syntactic theory. New York: Palgrave.

Qamariah, H. (2015). How a sentence is constructed: A syntactic analysis on ESL's writing text. Gegetsempena English Education Journal 2(2), 58-81. doi:10.46244/geej.v2i2.692.

Quirk, R. \& Greenbaum, S. (1973). A university of grammar of English. London: Longman.

Radford, A. (1997). Syntax: A minimalist introduction. Cambridge: Cambridge University Press.

Reyner, K. (2016). The interaction of syntax and semantic during sentence processing: Eye movements in the analysis of semantically based sentences. Massachusetts: Elsevier Inc.

Roberts, P. (1964). English syntax. New York: Harcourt, Brace \& World.

Streefkerk, R. (2020). Qualitative vs. quantitative research. Retrieved from https://www.scribbr.com/methodology/qualitative-quantitative-research (accessed in July 2020)

Thomas, L., \& Wareing, S. (Ed.). (1999). Language, society, and power. London: Routledge.

Valin, R. D. V. \& Lapolla, R. J. (1997). Syntax: Structure, meaning, and function. New York: Cambridge University Press.

Wiredu, J. F. (2012). A grammar of newspaper editorial language: The complex sentence. Legon Journal of the Humanities, 23, 75-124.

Yasmin, A. R. Indrawati, N. L. K. M., \& Rahayuni, N. K. S. (2017). Syntactic analysis of headline structure in the Jakarta Post online. Jurnal Humanis, 19(1), 7-73.

Ziyayeva, D. (2020). Verbs of speech activity in the newspapers. Theoretical and Applied Science, 84(4), 1005-1008. doi: 10.15863/TAS.2020.04.84.185. 